as much as fifteen cells. He agreed with Dr. Sachs as to the clinical symptoms and the reduction of the Wassermann. In answer to Dr. Kaliski and his statement that the administration of saline had changed the Wassermann, he would like to know the spinal fluid pressure before and after administration and the interval that elapsed between observations.

Dr. Kaliski said the Wassermann was taken before the introduction of the drug. At least a week elapsed between tests. It was not a dilution, in other words. He did not remember about the pressure.

Dr. Byrnes, in answer to Dr. Sachs, stated that he had recorded no bad results.

\title{
CHICAGO NEUROLOGICAL SOCIETY
}

\section{FEBRUARY 25, I9I5}

The President, Dr. H. Douglas Singer, in the Chair

\section{TRIBUTE TO DR. D'ORSAY HECHT}

Dr. Archibald Church said he was privileged to say a few words in reference to their colleague, friend, and fellow-worker, Dr. D'Orsay Hecht. During the larger part of his professional residence in Chicago Dr. Church was intimately associated with him. He did not propose, to indulge in eulogies. In this instance the cynical aphorism of "nil nisi" regarding the dead is accurately applicable without reservation to the real facts of a life so untimely ended.

Dr. Hecht's first impression upon him was one of cleanliness. He was cleanly in his dress-fastidiously so. At first it gave Dr. Church an idea that he was superficial, but he found that the same painstaking care that he exercised in the selection and wearing of his outer garments, he exercised in every endeavor and duty, and all his mental habiliments were equally clean. Very shortly he came to recognize that if anything were asked of Hecht it would be done. He was entirely dependable.

In his early writings there was a wordy excess that he very promptly overcame. In some of his later articles there is a terseness associated with directness that is highly satisfactory. If one turns to the papers that he prepared upon the injection of the fifth nerve branches and the treatment of the sciatic, he will find a lucid description of the technique and a practical guidance for the maneuvers that are unequalled in any other publication.

As a speaker and teacher he quickly acquired a facility of the highest order. On suitable occasions wit and humor were his ready servants: His ideas not only were formulated clearly but powerfully and logically presented.

With him his profession was in very fact a calling. To its highest ideals he was deeply devoted. In it he had already accomplished much, though he only stood upon the threshold of a career that promised the loftiest rewards and many eminent achievements.

Dr. Church had seen Dr. Hecht under varying circumstances-circumstances that were agreeable to him, circumstances that were trying to him. He had never known him to lose his poise or to take advantage in any fashion that was not straightforward. He was cleanly throughout. 
As a physician he had extraordinarily good qualities. He did his own thinking. He listened to others. He read all but formed his own opinions. He held his patients with a peculiar grip, not so much by personal attachment as by a mutual regard and respect that were unusual. Dealing as he did, and as the rest of us do, with a self-centered, egotistical and carping class of patients, in such gossip as has been forced upon all, Dr. Church had never heard any complaint of his personal or professional treatment of any patient.

Dr. Hecht had a nobility about him that was clearly manifest in the last days of his life. Although Dr. Church came into intimate contact with him and was aware of his ill health, and only a short time before his death arranged for a cessation of his school work in order that he might take a rest, he never complained to him that there was anything of a grave nature in his condition. And yet Dr. Church had since learned that for a long time he was advised that he stood in danger. He cheerfully met this danger without parading it, and with an optimism and a courage that are worthy of emulation. Dr. Church felt grateful to have known D'Orsay Hecht and entered deeply into the bereavement of those who were related to him. He requested the Society to rise for a solemn moment and stand in silence, as a tribute to this noble young soul who has gone out ahead of them.

(The Society rose as requested.)

\title{
TREATMENT OF PARESIS BY ENDO-LUMBAR INJECTION OF NEO-SALVARSAN
}

\author{
By Charles F. Read, M.D.
}

Twenty cases of well-advanced paresis in male subjects were treated with 123 endo-lumbar injections of neo-salvarsan, in doses ranging from .003 to .006 and .008 gram, diluted in at least ro $\mathrm{cc}$. of the patient's own fluid and given at intervals of two weeks. A number of patients received as high as ten doses. During the treatment, three patients died, but two of these were in the final stages of the disease when treatment was instituted and death cannot be fairly attributed to interference. One case, already slightly spastic when received, became quite intensely spastic and died after about three months' treatment. Three patients suffered incontinence of urine, apparently as a result of dosages of .006 gram. A few complained of weakness, headache and leg pains from time to time following treatments. A few had a slight rise of temperature for a short time following some treatments. One case of tabo-paresis developed a Charcot's joint during treatment. One suffered convulsions immediately after treatment, but had had other convulsions not connected with treatment. The Wassermann upon the blood serum in nine cases remained strongly positive. In one case it became negative and in another case it remained negative. The others were not tested. One negative and one faintly positive Wassermann in the spinal fluid became strongly positive.

A few favorable results were noted. In one case a very good remission began after a few treatments, but the spinal fluid findings are still positive. Others are markedly improved but are still very evidently paretics. A number showed improved physical health. In three cases the Wassermann upon the spinal fluid became weaker. 